\title{
Vacquinol-1 inducible cell death in glioblastoma multiforme is counter regulated by TRPM7 activity induced by exogenous ATP
}

\author{
Philip Sander ${ }^{1}$, Haouraa Mostafa ${ }^{1}$, Ayman Soboh ${ }^{1}$, Julian M. Schneider ${ }^{1}$, Andrej \\ Pala $^{2}$, Ann-Kathrin Baron ${ }^{3}$, Barbara Moepps ${ }^{4}$, C. Rainer Wirtz ${ }^{2}$, Michael Georgieff ${ }^{5}$ \\ and Marion Schneider ${ }^{1}$ \\ ${ }^{1}$ Division of Experimental Anesthesiology, University Hospital Ulm, 89081 Ulm, Germany \\ ${ }^{2}$ Department of Neurosurgery, Bezirkskrankenhaus Guenzburg, 89312 Guenzburg, Germany \\ ${ }^{3}$ Department of Operative Dentistry and Periodontology, University Hospital UIm, 89081 Ulm, Germany \\ ${ }^{4}$ Institute of Pharmacology and Toxicology, University Hospital UIm, 89081 UIm, Germany \\ ${ }^{5}$ Department of Anesthesiology, University Hospital UIm, 89081 UIm, Germany \\ Correspondence to: Marion Schneider, email: marion.schneider@uni-ulm.de \\ Keywords: glioblastoma multiforme, Vacquinol-1, ATP, TRPM7, methuosis \\ Received: February 03, $2017 \quad$ Accepted: March 15, $2017 \quad$ Published: March 30, 2017 \\ Copyright: Sander et al. This is an open-access article distributed under the terms of the Creative Commons Attribution License \\ (CC-BY), which permits unrestricted use, distribution, and reproduction in any medium, provided the original author and source \\ are credited.
}

\section{ABSTRACT}

Glioblastomas (GBM) are the most malignant brain tumors in humans and have a very poor prognosis. New therapeutic options are urgently needed. A novel drug, Vacquinol-1 ( $\mathrm{Vac}$ ), a quinolone derivative, displays promising properties by inducing rapid cell death in GBM but not in non-transformed tissues. Features of this type of cell death are compatible with a process termed methuosis. Here we tested Vac on a highly malignant glioma cell line observed by long-term video microscopy. Human dental-pulp stem cells (DPSCs) served as controls. A major finding was that an exogenous ATP concentration of as little as $1 \mu \mathrm{M}$ counter regulated the Vac-induced cell death. Studies using carvacrol, an inhibitor of transient receptor potential cation channel, subfamily M, member 7 (TRPM7), demonstrated that the ATP-inducible inhibitory effect is likely to be via TRPM7. Exogenous ATP is of relevance in GBM with large necrotic areas. Our results support the use of GBM cultures with different grades of malignancy to address their sensitivity to methuosis. The video-microscopy approach presented here allows decoding of signaling pathways as well as mechanisms of chemotherapeutic resistance by long-term observation. Before implementing Vac as a novel therapeutic drug in GBM, cells from each individual patient need to be assessed for their ATP sensitivity. In summary, the current investigation supports the concept of methuosis, described as non-apoptotic cell death and a promising approach for GBM treatment. Tissue-resident ATP/necrosis may interfere with this cell-death pathway but can be overcome by a natural compound, carvacrol that even penetrates the blood-brain barrier.

\section{INTRODUCTION}

Approximately $30 \%$ of all primary brain tumors are diagnosed as Glioblastoma multiforme (GBM), a highly fatal malignancy with high mutagenicity and extreme migration and invasion potentials, explaining the poor survival rate [1]. In addition to standard radiochemotherapy inducing apoptosis-related cell death, new effective therapeutic modalities for GBM are urgently required. Established apoptosis-directed therapy has not resulted in an improved prognosis [2]. Importantly, GBM disseminate within the brain and lack hematogenous spreading [3-5]. Nevertheless, major changes of the patients' immune system are consistently found [6], implying an as yet not fully understood crosstalk between the tumor environment and hematological/immunological elements. Alterations of the immune system are relevant to survival $[6,7]$. 
Only recently, screening of a small molecule library (NCI-DTP Diversity Set II) revealed a quinolone substance termed Vacquinol-1 (Vac), which induces a novel form of a cell death that appears to be highly restricted to GBM [8]. Characteristics of Vac-induced glioma cell death include cell blebbing followed by rupture of the plasma membrane. In situ, GBMs contain large areas of necrotic tissue [9, 10], which are likely to be ATP-rich [11]. Extracellular ATP is an important signaling molecule that acts via purinergic receptors and ion channels $[12,13]$. Moreover, extracellular ATP possesses a growth-promoting effect on glioma cells [14], and may act through metabotropic P2Y and ionotropic $\mathrm{P} 2 \mathrm{X}$ receptors [12]. Therefore, we considered whether ATP might influence Vac-inducible cell death. In addition to purinergic receptors, ATP can lead to activation of the ubiquitously expressed transient receptor potential cation channel, subfamily M, member 7 (TRPM7) cation channel [15]. TRPM7 plays a role in several cancer types, including breast cancer [16], gastric cancer [17] and pancreatic cancer [18]. The high physiological relevance of TRPM7 for GBM was recently demonstrated by the remarkable growth-inhibitory effect when TRPM7 was blocked [19]. Chen and colleagues demonstrated that the tumoricidal activity of the natural terpenoid carvacrol was through TRPM7 inhibition [19]. In this study, we addressed Vac-inducible cell death in an extremely aggressive glioblastoma cell line (\#12537-GB) and its sensitivity to ATP using long-term observation by live cell imaging (IncuCyteZOOM ${ }^{\circledR}$, Essenbio.com, USA). Results provide evidence for i) Vac-induced cell death in GBM-derived cell lines, but not in dental-pulp stem cells (DPSCs), and ii) the potential of ATP-induced counter regulation. The ATP-related effects appear to be mediated by TRPM7 and are sensitive to carvacrol. One important rationale to address ATP induced effects arises from its properties to function as a danger signal in solid tumors [20].

\section{RESULTS}

\section{Vac induces rapid cell death in glioma cell lines and is sensitive to exogenous ATP}

In the present study, we investigated the kinetics of Vac on the viability of the established glioma cell line U-87 and the new, highly aggressive glioma cell line designated \#12537-GB, and thus confirmed and extended endpoint observations reported by Kitambi and colleagues [8]. To determine cell viability of preestablished cell layers, we applied the live cell imaging system IncuCyteZOOM ${ }^{\circledR}$ equipped with a $10 \times$ objective and used propidium iodide (PI) staining to determine cell death. Vac concentrations of $0.07 \mu \mathrm{M}$ and $0.7 \mu \mathrm{M}$ were applied to \#12537-GB, but there was no significant effect on cell viability (IncuCyteZOOM ${ }^{\circledR}$, kinetics of cell death for $43 \mathrm{~h})$. With high Vac concentrations (14 $\mu \mathrm{M}, 28 \mu \mathrm{M})$, glioma cells died in $<2 \mathrm{~h}$ (Supplementary Figure 1). For further experiments, we chose a Vac concentration of 7 $\mu \mathrm{M}$ for all kinetic analyses. Figure 1 shows the results of continuous imaging of both phase contrast and red fluorescence over a period of $16 \mathrm{~h}$ (\#12537-GB), $45 \mathrm{~h}$ (U-87), or 48 h (DPSCs), with frames taken at 15-120min intervals. Red fluorescence corresponding to dead cells ranged between $2-5 \%$ of the total population in U-87 and \#12537-GB control cell layers (Figure 1A, 1B). When trying to interfere with Vac-induced cell death, we identified that exogenous ATP exhibited the most pronounced counter regulatory effect (Figure 1A, 1B). Within $1.25 \mathrm{~h}$ of observation, Vac treatment of the \#12537-GB cell line already differed significantly in viability from untreated controls (two-way analysis of variance (ANOVA), $\mathrm{p}<0.0001$ ), Figure $1 \mathrm{~A})$. In contrast, viability impaired by Vac treatment of U-87 only differed at $8 \mathrm{~h}$ from untreated controls (Figure 1B). The time point of greatest differences between $\mathrm{Vac}$ and Vac+ATP treatments is illustrated in the right columns of Figure 1. After $4 \mathrm{~h}$ of incubation, the differences in PI fluorescence corresponding to cell death were significant in \#12537GB (multiple comparison two-way ANOVA, $\mathrm{p}<0.0001$ : control/Vac; $\mathrm{p}<0.0001$ : $\mathrm{Vac} / \mathrm{Vac}+\mathrm{ATP})$. However, in $\mathrm{U}-87$, the time point of greatest difference was observed later, at $25 \mathrm{~h}$ of incubation (multiple comparison twoway ANOVA, $\mathrm{p}<0.0001$ : control/Vac; $\mathrm{p}=0.0012$ : Vac/ Vac+ATP). The results were compared with DPSCs, a stem cell line from third molars (Figure 1C). Vac-treated DPSCs did not display any significant PI uptake during the observational period (Figure $1 \mathrm{C}$ ). The right column of Figure $1 \mathrm{C}$ illustrates PI uptake after $4 \mathrm{~h}$ of incubation in DPSCs, which was not significant after treatment. Taken together, Vac-induced cell death is sensitive to the counter regulatory effect by ATP, following cell-specific kinetics: Vac induced almost 100\% cell death in \#12537-GB within $16 \mathrm{~h}$ of incubation whereas $\mathrm{U}-87$ cells responded in a delayed fashion, with cell death still on-going after $45 \mathrm{~h}$ of incubation.

\section{Vac-induced cell death coinciding caspase 3/7 activation is counter regulated by exogenous ATP in glioma cell lines}

We then investigated whether Vac-induced cell death was related to apoptosis. Therefore, caspase 3/7 was quantified using enzyme-activity assays (Essenbio. com), generating a green fluorescent signal detectable by IncuCyteZOOM ${ }^{\circledR}$-assisted live cell imaging over a period of $16 \mathrm{~h}$ (Figure 2A). Vac rapidly induced an increase in caspase $3 / 7$ activity, reaching a maximum after $6 \mathrm{~h}$ (Figure 2A). Vac-induced caspase $3 / 7$ activation is sensitive to exogenous ATP. When the two time curves were compared over the period 0-16 $\mathrm{h}$, differences determined by twoway ANOVA were highly significant $(p<0.0001)$; Figure 

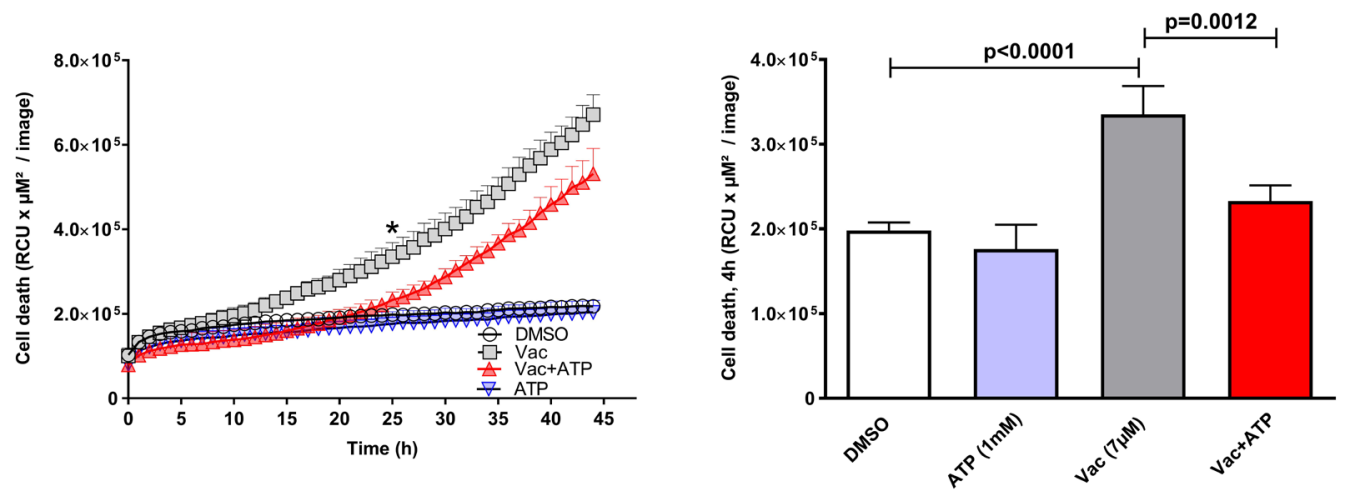

B

\#12537-GB
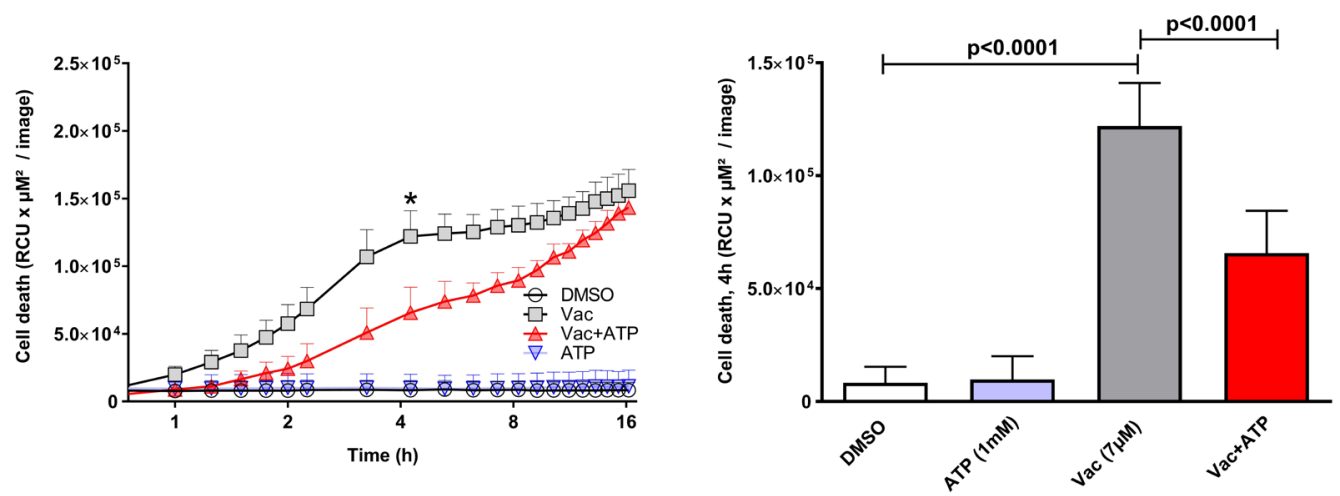

C

DPSCs
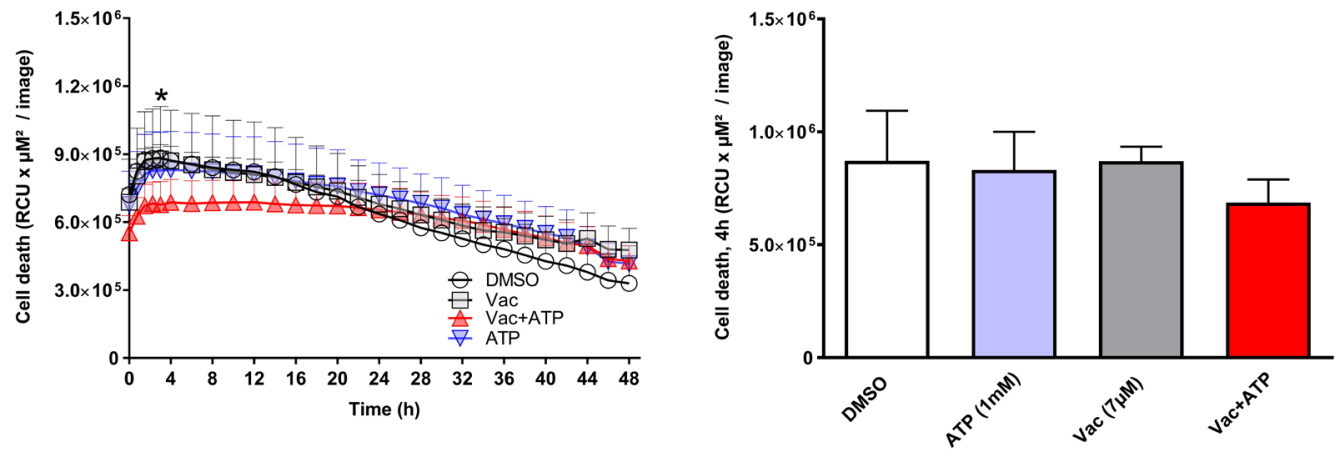

Figure 1: Vac efficiently kills glioma cells in an ATP-sensitive manner, but does not affect DPSCs. Kinetics of cell death were determined from the PI-positive (dead) cells displayed as relative color units (RCU) per $\mu \mathrm{M}^{2} /$ image (y-axis, left column). U-87 cells were followed for $45 \mathrm{~h}$ (x-axis) (IncuCyteZOOM ${ }^{\circledR}$ ). DMSO diluted in medium at $10^{-4}$ served as control; $7 \mu \mathrm{M} \mathrm{Vac}$; Vac + ATP $1 \mathrm{mM}$; and 1 mM ATP alone (A, left). Quantitative analysis of cell death determined at $25 \mathrm{~h}(*)$ was significantly different for Vac vs. control (multiple comparison two-way ANOVA, $\mathrm{p}<0.0001$ ) and Vac vs. Vac + ATP (multiple comparison two-way ANOVA, $\mathrm{p}=0.0012$ ) (A, right). Cell death of \#12537-GB cells was followed for $16 \mathrm{~h}$ (x-axis, $\log 2$ scale). DMSO $\left(10^{-4}\right)$ control; $7 \mu \mathrm{M}$ Vac; Vac + ATP $1 \mathrm{mM}$; and $1 \mathrm{mM}$ ATP alone (B, left). Quantitative analysis at $4 \mathrm{~h}\left({ }^{*}\right)$ was significantly different for Vac vs. control and Vac vs. Vac + ATP (both $\mathrm{p}<0.0001$ by multiple comparison two-way ANOVA) (B, right). Kinetics of cell death determined by PI-positive (dead) DPSCs (RCU $\times \mu \mathrm{M}^{2} / \mathrm{image}$ ) were followed for $48 \mathrm{~h}\left(\right.$ IncuCyteZOOM ${ }^{\circledR}$ ). DMSO $\left(10^{-4}\right)$ control; $7 \mu \mathrm{M}$ Vac; Vac + ATP $1 \mathrm{mM}$; and $1 \mathrm{mM}$ ATP alone (C, left). Quantitative analysis at $4 \mathrm{~h}$ (*) for DPSCs (C, right). All values are given as means \pm SD (triplicate values). The analyses were performed with 5,000 cells seeded per

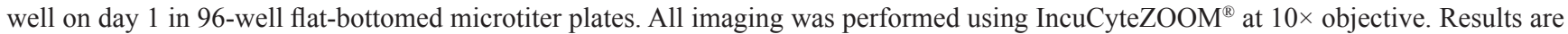
representative of 3 independent experiments. 
2B shows the significances of the differences in cell death determined after $2 \mathrm{~h}$ of observation using multiple comparison two-way ANOVA $(\mathrm{p}<0.0001$ : control/Vac; $\mathrm{p}<0.0001$ : $\mathrm{Vac} / \mathrm{Vac}+\mathrm{ATP})$. In addition, caspase $3 / 7$ activity measurements using luminescence-based endpoint caspase $3 / 7$ assay confirmed a significant increase in caspase $3 / 7$ activity after $2 \mathrm{~h}$ of incubation in \#12537-GB cells (Figure

A
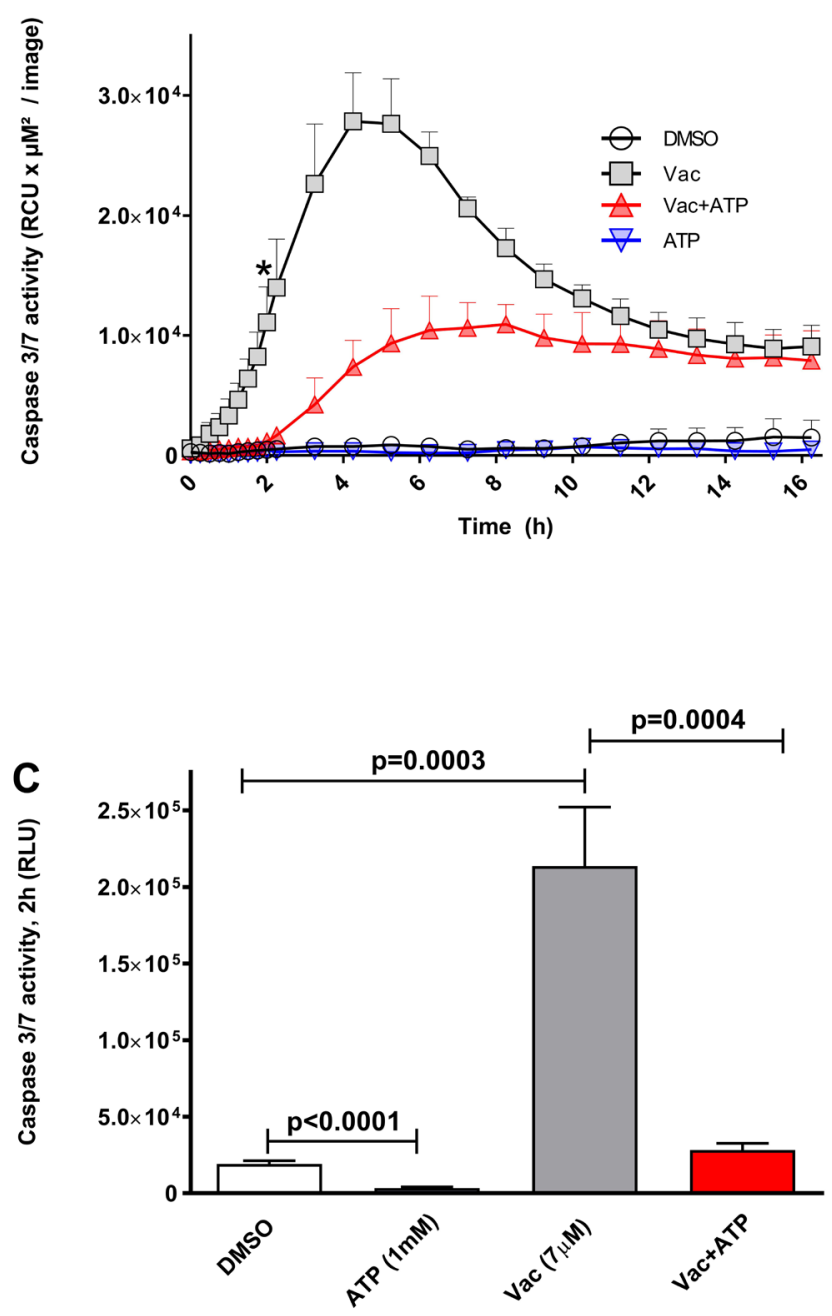

2C, t-test, $\mathrm{p}=0.0003$ : control/Vac) and in U-87 cells (Figure 2D, t-test, $\mathrm{p}=0.0056$ : control/Vac). The observed upregulation of caspase $3 / 7$ was sensitive to $1 \mathrm{mM}$ ATP in \#12537-GB (Figure 2C, t-test, $\mathrm{p}=0.0004$ ) and in $\mathrm{U}-87$ (Figure 2D, t-test, $\mathrm{p}=0.0005$ ). ATP at $1 \mathrm{mM}$ also attenuated spontaneous caspase $3 / 7$ activity in both cell lines (t-test, $\mathrm{p}<0.0001$ : Figure 2C, 2D).
B
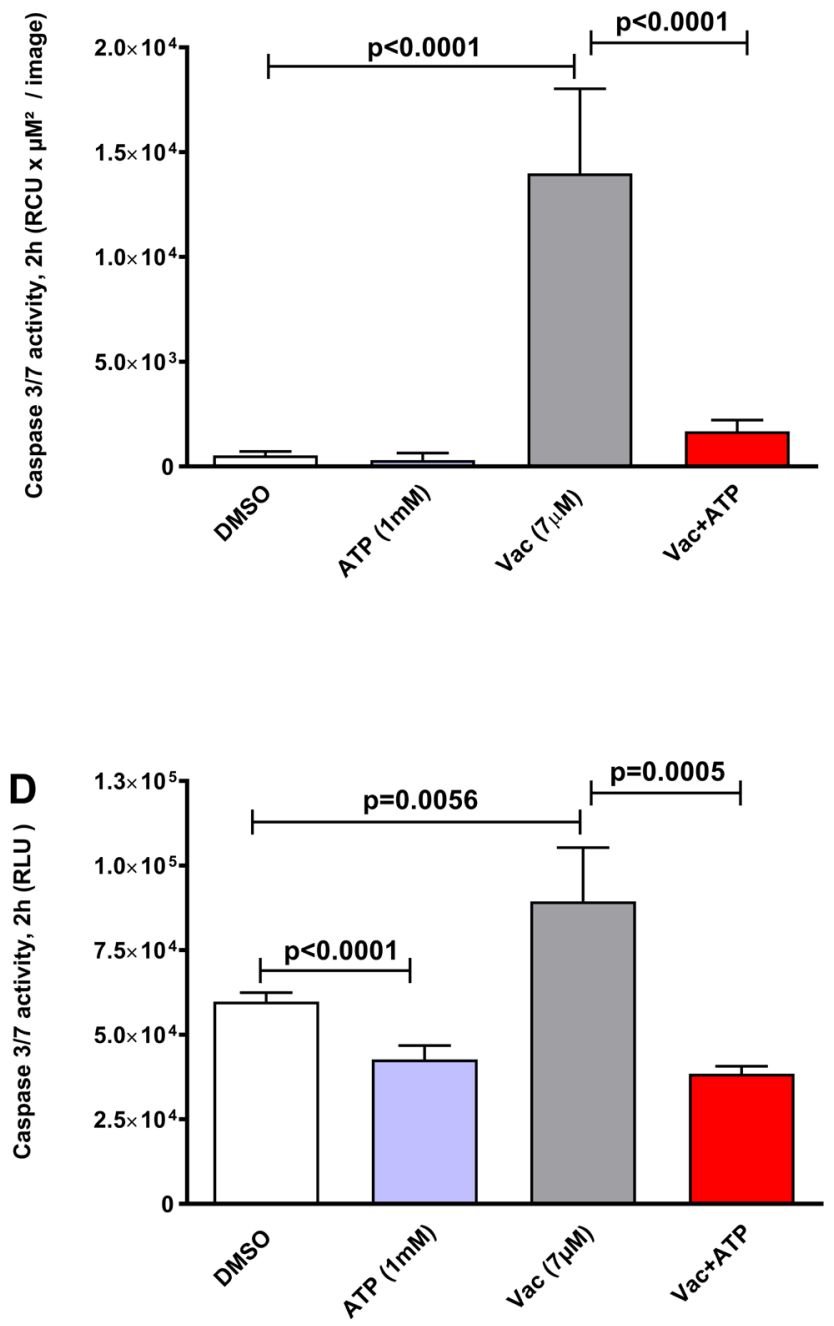

Figure 2: Vac leads to caspase $3 / 7$ activation in glioma cells, counter regulated by ATP. Caspase 3/7 activity given as relative color units (RCU) per $\mu \mathrm{M}^{2}$ /image. Semi-confluent glioma cells (seeded in 96-well flat-bottomed microtiter plates) were treated with DMSO diluted in medium at $10^{-4}$ served as control; $7 \mu \mathrm{M} \mathrm{Vac}$; Vac + ATP $1 \mathrm{mM}$; and $1 \mathrm{mM}$ ATP alone. Caspase 3/7 activity was monitored over $16 \mathrm{~h}$ (x-axis) (IncuCyteZOOM ${ }^{\circledR}$ ) by adding IncuCyte ${ }^{\circledR}$ Caspase-3/7 reagent (y-axis, RCU $\times \mu \mathrm{M}^{2} /$ image) $(\mathbf{A})$. Quantitative analysis at $2 \mathrm{~h}$ for glioma cells (* in A). Vac vs. control and Vac vs. Vac+ATP (both $\mathrm{p}<0.0001$ by multiple comparison two-way ANOVA). (B). All values are given as means $\pm \mathrm{SD}$ (triplicate values). All imaging was performed using IncuCyteZOOM ${ }^{\circledR}$ at $10 \times$ objective. Caspase $3 / 7$ activity (Promega.com) in \#12537-GB at $2 \mathrm{~h}$ of incubation ( $6 \times$ replicates); RLU (y-axis) (C). Vac leads to increased caspase $3 / 7$ activity compared to controls ( $\mathrm{t}$-test, $\mathrm{p}=0.0003$ ); ATP counter regulates the Vac-induced caspase $3 / 7$ activation (t-test, $\mathrm{p}=0.0004)$; exogenous ATP influences spontaneous caspase 3/7 activity compared to the DMSO control (t-test, $\mathrm{p}<0.0001$ ). Caspase $3 / 7$ activity in U-87 determined by a luminescence-based assay $(\mathrm{n}=6)$ after $2 \mathrm{~h}$ of incubation (Caspase Glo 3/7, Promega.com) given as RLU (y-axis) with background subtracted. Vac leads to increased caspase $3 / 7$ activity compared to the DMSO control (t-test, $p=0.0056$ ); ATP counter regulates the Vacinduced caspase $3 / 7$ activation (t-test, $\mathrm{p}=0.0005$ ); exogenous ATP affects spontaneous caspase $3 / 7$ activity compared to the DMSO control (t-test, $\mathrm{p}<0.0001)$ (D). All values are given as means $\pm \mathrm{SD}(6 \times$ replicates $)$. All analyses were performed with 5,000 cells seeded per well on day 1 in 96-well flat-bottomed microtiter plates. Results are representative of 3 independent experiments. 


\section{Vac induces cell death through caspase $3 / 7$ activation but cell death remains morphologically distinct from apoptosis induced by staurosporine (STS)}

To compare Vac-induced cell death with typical apoptosis, cells were treated with either $7 \mu \mathrm{M}$ Vac or $1 \mu \mathrm{M}$ STS. STS is a potent inducer of caspase $3 / 7$ and apoptosis [21]. Cell death was monitored over time (20 h) by PI staining and IncuCyteZOOM ${ }^{\circledR}$-assisted live cell imaging (Figure 3A). Although both STS- and Vacinduced cell death, according to PI uptake this was delayed with STS compared to Vac (Figure 3A). Luminescencebased caspase 3/7 assays showed increased caspase 3/7 activity by STS after $4 \mathrm{~h}$ (t-test, $\mathrm{p}=0.0038$ : STS vs.Vac). To summarize, despite caspase $3 / 7$ activation, Vacinducible cell death at $7 \mu \mathrm{M}$ did not lead to an apoptotic phenotype, which includes nuclear fragmentation; instead, glioblastoma cells died by vacuolization and eventual rupture of the plasma membrane (Figures 3C, 3D; Supplementary Figure 2), facilitating rapid PI uptake (Figures 1A, Supplementary Figure 2). In \#12537GB, these effects occurred earlier than in STS-induced apoptosis. Therefore, Vac-induced cell death appears to circumvent apoptosis but does involve caspase $3 / 7$ activation. Co-incubation with the pan-caspase inhibitor carbobenzoxy-valyl-alanyl-aspartyl-[O-methyl]-

fluoromethylketone (zVAD-FMK) $(40 \mu \mathrm{M})$ (Promega. com, USA) resulted in a delay of Vac-induced cell death (two-way ANOVA, $\mathrm{p}<0.0001$; Supplementary Figure 3). Even in the presence of the caspase inhibitor, $100 \%$ cell death occurred later, suggesting a cooperative effect of caspase activities in Vac-induced cell death.

\section{Vac-induced cell death is sensitive to micromolar ATP levels}

Purinergic receptors differ in ATP binding affinities (reviewed in [12]), and receptor involvement may be deduced by determination of the ATP concentration with the greatest biological effect. Of note, using flow cytometry, P2X4 and P2X7 expression was verified in \#12537-GB (Supplementary Figure 4).

Therefore, ATP was titrated between $10 \mathrm{nM}$ and $1 \mathrm{mM}$ into cultures with and without a constant Vac concentration of $7 \mu \mathrm{M}$ (Figure $4 \mathrm{~A}$ ). Co-titration of $1 \mu \mathrm{M}$, $10 \mu \mathrm{M}, 100 \mu \mathrm{M}$ and $1 \mathrm{mM}$ ATP led to significantly reduced PI uptake compared to Vac alone (two-way ANOVA, $\mathrm{p}<0.0001)$. By contrast, $100 \mathrm{nM}$ ATP had no effect on Vac-induced cell death, whereas as little as $10 \mathrm{nM}$ ATP resulted in a significant increase of Vac-induced cell death (two-way ANOVA, $\mathrm{p}<0.0001$; Figure 4A). Multiple ATPbinding receptors differing in ATP binding affinities may be involved. To specifically address the involvement of purinergic receptors on the ATP-mediated salvage effect, we added suramin as a universal P2-receptor inhibitor (Figure 4B) or the selective P2X7 inhibitor A-438079 (Figure 4C). Both inhibitors increased the ATP-mediated counter regulatory effect on Vac-induced cell death. These findings imply that purinergic signaling does not contribute to the observed ATP-related counter regulatory effect. Similar to arguments communicated in a recent study by Noerenberg et al. [13], we addressed the ubiquitously expressed TRPM7 to explain the ATPmediated salvage effect on Vac-induced cell death. To prove the involvement of TRPM7, we applied carvacrol as a reversible TRPM7 inhibitor.

\section{Carvacrol supports Vac-induced cell death and prevents the ATP-mediated recovery effect on Vac}

In our approach to test the involvement of TRPM7, we quantified its expression by quantitative real-time PCR (qPCR) in glioma cell lines (\#12537GB, U-87) as well as in DPSCs. Accordingly, all cell lines expressed TRPM7, but expression in glioma cell lines (\#12537-GB, U-87) was stronger than in dental stem cells (DPSCs) (Supplementary Figure 5). Moreover, the Vac-induced cell death and the observed ATP-mediated inhibitory effect on Vac-induced cell death were sensitive to carvacrol when co-incubated at $50 \mu \mathrm{M}$ and $100 \mu \mathrm{M}$ (Figure 5A). Cell death was monitored from $0-24 \mathrm{~h}$. Carvacrol at $100 \mu \mathrm{M}$ alone did not affect baseline glioma cell viability, but significantly stimulated $7 \mu \mathrm{M}$ Vac-induced glioma cell death (twoway ANOVA, $\mathrm{p}<.0 .0001$ : Vac/Vac + carvacrol $100 \mu \mathrm{M}$; Figure 5A). Moreover, $50 \mu \mathrm{M}$ and $100 \mu \mathrm{M}$ carvacrol impaired the ATP- $(1 \mathrm{mM})$ mediated recovery effect on Vac-induced cell death (two-way ANOVA, $\mathrm{p}<0.0001$ ) (Figure 5B). Figure 5C summarizes the quantitative differences on glioma cell death of Vac and the influence of ATP $(1 \mathrm{mM})$ and carvacrol $(50 \mu \mathrm{M}$ and $100 \mu \mathrm{M})$ after $8 \mathrm{~h}$, the time of greatest increment values. Because carvacrol blocks TRPM7, these results suggest that the ATP effects were mediated through TRPM7.

\section{Hypothetical mechanism of action}

According to our current working hypothesis, which is schematically displayed in Figure 6, Vac induces massive vacuolization (V) followed by cell death, which is due to either inefficient vacuole-lysosome fusion or impaired degradation and extrusion of vacuole contents by the CD63 vesicles. Ion-flux induced by exogenous ATP in turn induces calcium-signaling in Fura-2 labeled \#12537-GB cells (Supplementary Figure 6). Exogenous ATP activates TRPM7, $\mathrm{Ca}^{++} / \mathrm{Mg}^{++}$influx, and phosphoinositide 3-kinase (PI3K) activation, which promotes vesicle fusion (V) with lysosomes (L), and subsequent degradation by CD63-targeted extrusion. TRPM7-specific effects are sensitive to carvacrol, which stimulates TRPM7-related cell death in GBM. 


\section{DISCUSSION}

The present investigation documents rapid Vacinduced cell death in the commercially available U-87 cell line and the highly malignant glioma cell line \#12537-GB, whereas non-malignant DPSCs remained unaffected. These findings mirror observations by Kitambi and colleagues on the highly specific action by Vac on GBM using established cell lines and their own isolates, but without affecting mouse embryonic stem cells, fibroblasts, mouse astrocytes and neurons [8]. The live cell imaging system IncuCyteZOOM ${ }^{\circledR}$ serves as a powerful tool for observing cell death in glioma cell lines, both morphologically and quantitatively (Figures $1-5)$. Vac-induced cell death is clearly independent from

A
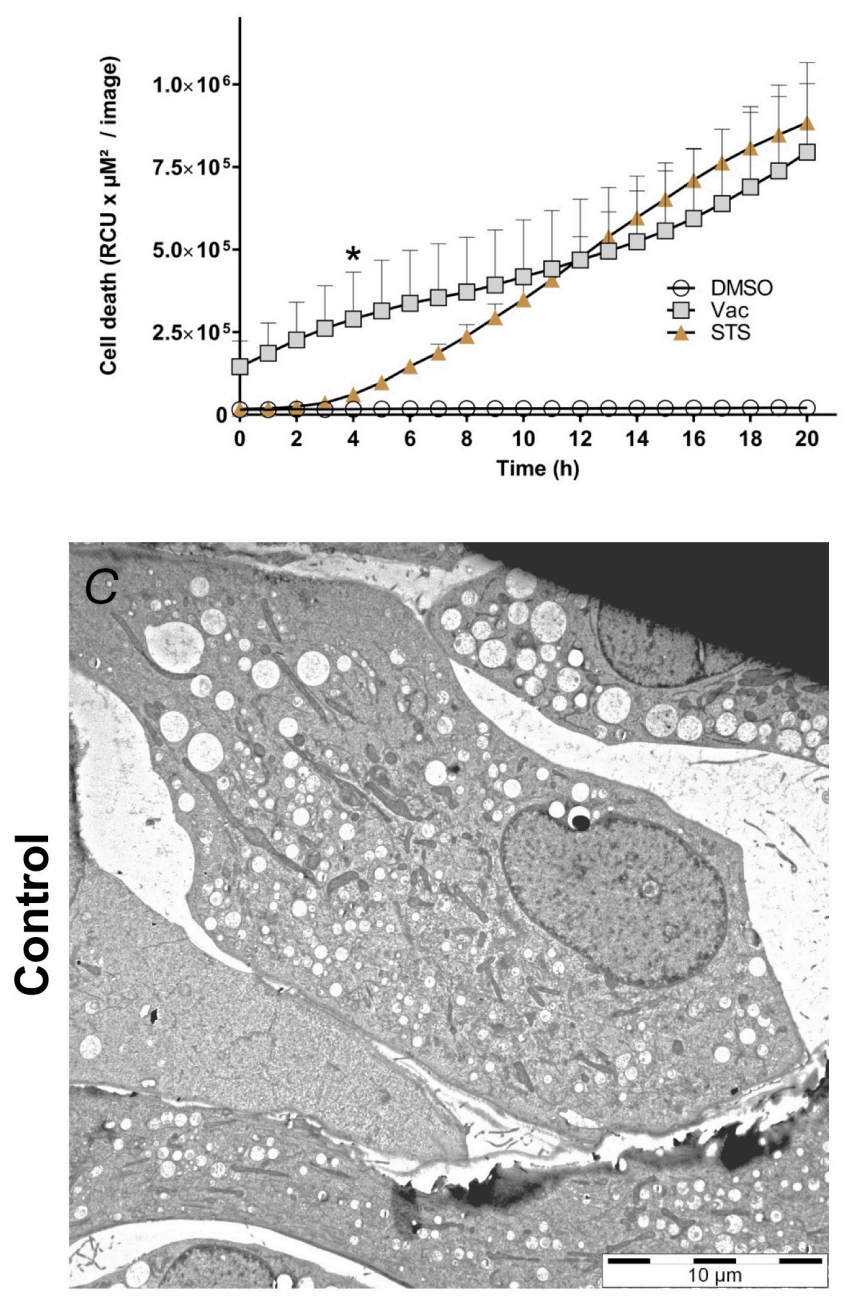

apoptosis [8] and displays intensive cell blebbing followed by immediate plasma-membrane rupture and subsequent PI uptake (Figures 1, 3 and Supplementary Figure 2), the latter is more a feature of necrosis [22]. This novel form of cell death was recently termed as methuosis [23]. These observations correspond with previous findings described by Kitambi et al. [8].

Cell death determined by PI-stained nuclei is significantly delayed in the presence of exogenous ATP. When we determined cell proliferation by confluence measurements (Supplementary Figure 7), the effect of ATP appeared to be independent from increased proliferation. However, in a different study, a growthpromoting effect by ATP was reported in gliomas [14], which makes additional investigations necessary to
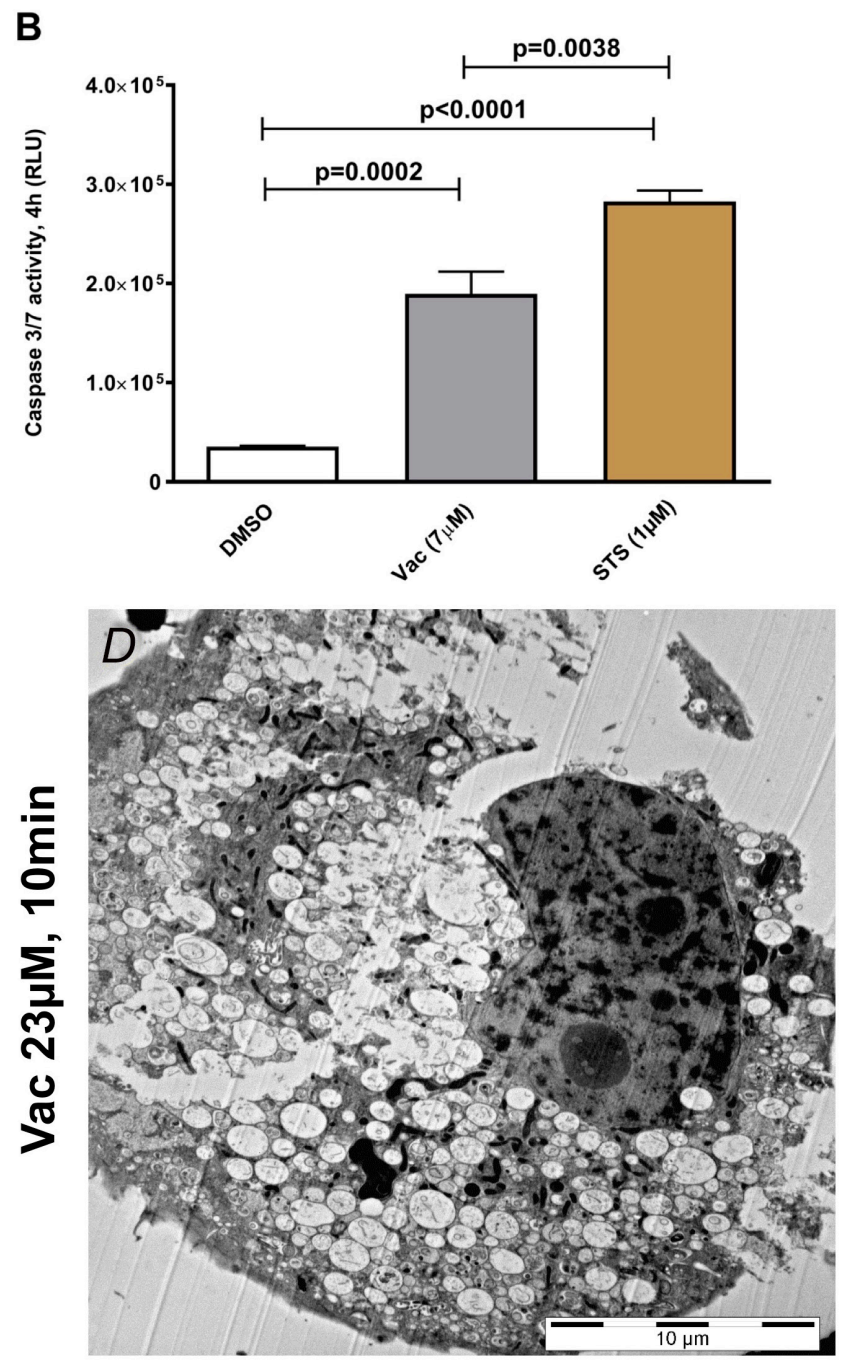

Figure 3: Vac- vs STS-mediated cell death. Semi-confluent glioma cells (seeded in 96-well flat-bottomed microtiter plates) were treated with $2 \times 10^{-3}$ DMSO diluted in medium served as control, $7 \mu \mathrm{M}$ Vac or $1 \mu \mathrm{M}$ STS. Cell death was monitored over $20 \mathrm{~h}$ (x-axis) by PI staining (y-axis, RCU $\times \mu \mathrm{M}^{2} /$ image). All values are given as means $\pm \mathrm{SD}$ ( $8 \times$ replicates) (A). All imaging was performed using IncuCyteZOOM ${ }^{\circledR}$ at $10 \times$ objective. Caspase $3 / 7$ activity was determined by luminescence assay (RLU, y-axis by Caspase Glo 3/7 assay, Promega.com) after $4 \mathrm{~h}(*, \mathrm{~A})$; control vs. Vac (t-test, $\mathrm{p}=0.0002)$; control vs. STS (t-test, $\mathrm{p}<0.0001)$; Vac vs. STS (t-test, $\mathrm{p}=0.0038)$. All values are means of RLU with background subtracted $\pm \mathrm{SD}(8 \times$ replicates $)$ (B). Representative transmission electron micrograph image of $\# 12537-\mathrm{GB}$ without (C) and with $23 \mu \mathrm{M}$ Vac (D) applied for $10 \mathrm{~min}$ at $37^{\circ} \mathrm{C}$. Specimens were processed by cryo-fixation. 
address ATP-responsive receptors and pathways in GBM. Because Vac likely acts similarly to small molecules of the chalcone family, which also mediate methuosis in GBM, a similar pathway may be involved [23-26]. According to Overmeyer and Maltese, methuosis induced by chalcones is Ras dependent [26] but the action profile of Vac has not been tested for Ras dependency. However, Kitambi and colleagues demonstrated that methuosis induced by Vac is MKK4 dependent [8], downstream of Ras/Rac-1 activation. In summary, further experiments need to address Ras/Rac-1/MKK4 signaling induced by both Vac and chalcones and its role in transformed and non-transformed cells. We here demonstrated that Vac is non-toxic against non-transformed DPSCs (Figure 1C), a potent regenerative stem-cell source [27]. Results confirmed previous observations regarding non-toxic effects on non-transformed tissues by Vac [8, 23]. Ras/ Rac-1 and eventually MKK4 signaling may constitute a GBM-specific weak point exploited by these drugs.
Overexpression of Rac-1 in GBM is likely to affect phagosome-lysosome fusion/degradation as schematically shown in Figure $6[21,22]$. Accordingly, the GBMspecific deficiency in late phagosome $\left(\mathrm{CD}^{+}\right)$[29] degradation results in methuosis by increased vacuole fusion events. Hypothetically (Figure 6), the ATP-recovery effect is mediated by purinergic receptors or TRPM channel family members, leading to $\mathrm{Ca}^{++}$and $\mathrm{Mg}^{++}$influx and PI3K activation. The latter may improve phagosome maturation and degradation [30, 31], and thereby attenuate the cytotoxic effect of Vac.

Vac-induced methuosis in GBM (\#12537-GB and U-87) also involves caspase 3/7, as demonstrated in Figure 2 , corresponding to results of Overmeyer and colleagues $[23,24]$. In detail, caspase 3 activation was restricted to glioma cells already being detached from the surface [24]. However, caspase $3 / 7$ is not essential for methuotic cell death $[8,26]$. According to Kitambi and colleagues, Vac does not induce caspase 3/7 activation [8]. By contrast, we

A

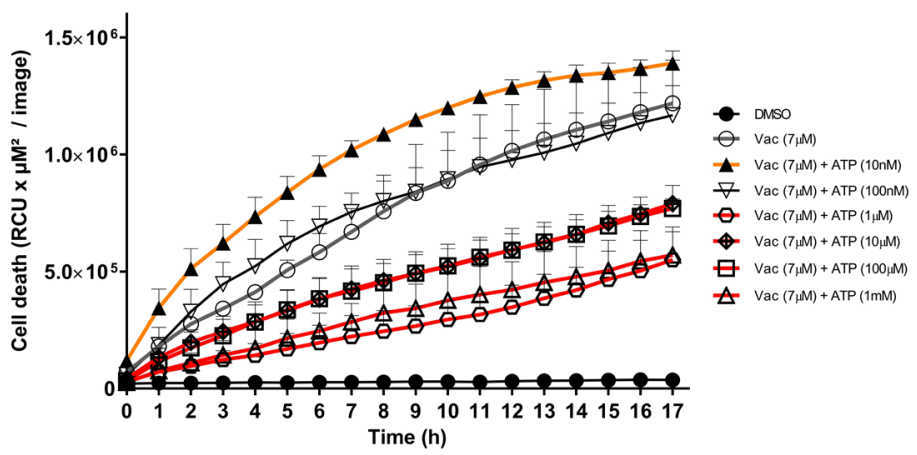

B

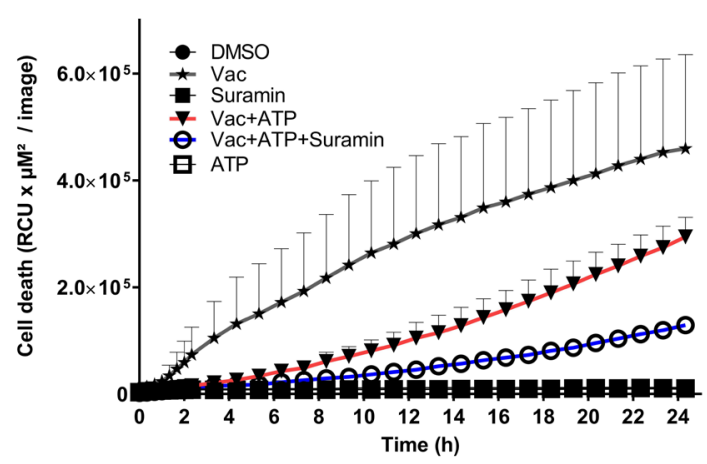

C

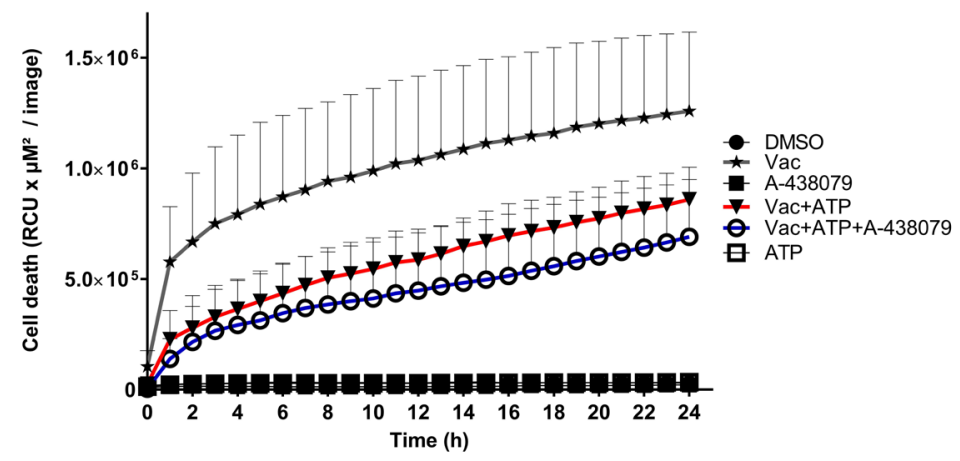

Figure 4: ATP concentrations interfering with Vac-induced cell death, inhibition by purinergic receptor inhibitors. Semi-confluent \#12537-GB cells (seeded in 96-well flat-bottomed microtiter plates) were treated with $7 \mu \mathrm{M}$ Vac with or without $10 \mathrm{nM}$, $100 \mathrm{nM}, 1 \mu \mathrm{M}, 10 \mu \mathrm{M}, 100 \mu \mathrm{M}$ and $1 \mathrm{mM}$ ATP, or DMSO diluted in medium at $10^{-4}$ served as control. PI-positive (dead) cells are given as RCU (y-axis, RCU $\times \mu \mathrm{M}^{2} /$ image). Glioma cells were followed for $17 \mathrm{~h}$ (x-axis). All values are means of PI fluorescence \pm SD (triplicate values) (A). Vac-induced cell death $(7 \mu \mathrm{M})$ (y-axis, $\mathrm{RCU} \times \mu \mathrm{M}^{2} /$ image) recorded for $24 \mathrm{~h}$ (x-axis) was attenuated by ATP (1 mM) but was further increased by ATP in the presence of the universal purinergic inhibitor Suramin $(30 \mu \mathrm{M})$. All values are means of PI fluorescence \pm SD (triplicate values) (B). Vac-induced cell death $(7 \mu \mathrm{M})$ (y-axis: RCU $\times \mu \mathrm{M}^{2} /$ image) recorded for $24 \mathrm{~h}$ (x-axis) was attenuated by ATP $(1 \mathrm{mM})$ but was further increased by ATP in the presence of the selective P2X7 inhibitor A-438079 $(100 \mu \mathrm{M})$. All values are means of PI fluorescence \pm SD (6× replicates) (C). All imaging was performed using IncuCyteZOOM ${ }^{\circledR}$ at $10 \times$ objective. Results are representative of 2 independent experiments. 
found that Vac induces caspase 3/7 activation (Figures 2, 3 ). In our caspase $3 / 7$ assays (Promega chemiluminescent assay and IncuCyteZOOM ${ }^{\circledR}$-based video microscopy), we analyzed caspase $3 / 7$ activity in both attached and detached cells. One possible explanation for our different findings regarding Vac-induced caspase $3 / 7$ activity could be that Kitambi and colleagues excluded the detached cells in their caspase assays. Although caspase $3 / 7$ is not essential for methuotic cell death $[8,22]$, we found that caspase $3 / 7$ activation as well as endogenous caspase $3 / 7$ activity is counter regulated by exogenous ATP (Figure 2). In the glioma cell line \#12537-GB, Vacinduced caspase $3 / 7$ activation and STS-induced apoptosis occur within a similar time frame (Figures 2, 3, [32,33]). However, the number of PI-positive nuclei in STS- and Vac-treated glioma cells differed between Vac- and STSinduced cell death (Figure 3A). Nuclear fragmentation, a characteristic of apoptotic cell death, was not observed in Vac-treated \#12537-GB cells (Figures 3, Supplementary Figure 2), corresponding to observations by Overmeyer and colleagues [26]. Taken together, Vac induces a necrotic-like cell death (methuosis) through sharing vacuolization and caspase $3 / 7$ activation (but no other features) characterizing apoptotic cell death. Caspase-3 activation has been reported to be involved in autophagic cell death [34]. Of note, autophagic cell death features vacuolization [35] and plasma-membrane rupture [36], considerable resembling the observation reported herein for Vac-induced cell death in GBM. However, whether autophagy plays a role in Vac-induced cell death awaits further experiments.

Titration of different ATP concentrations into \#12537-GB Vac assays antagonized Vac-induced cell death already from only $1 \mu \mathrm{M}$ ATP (Figure 4A). By
A
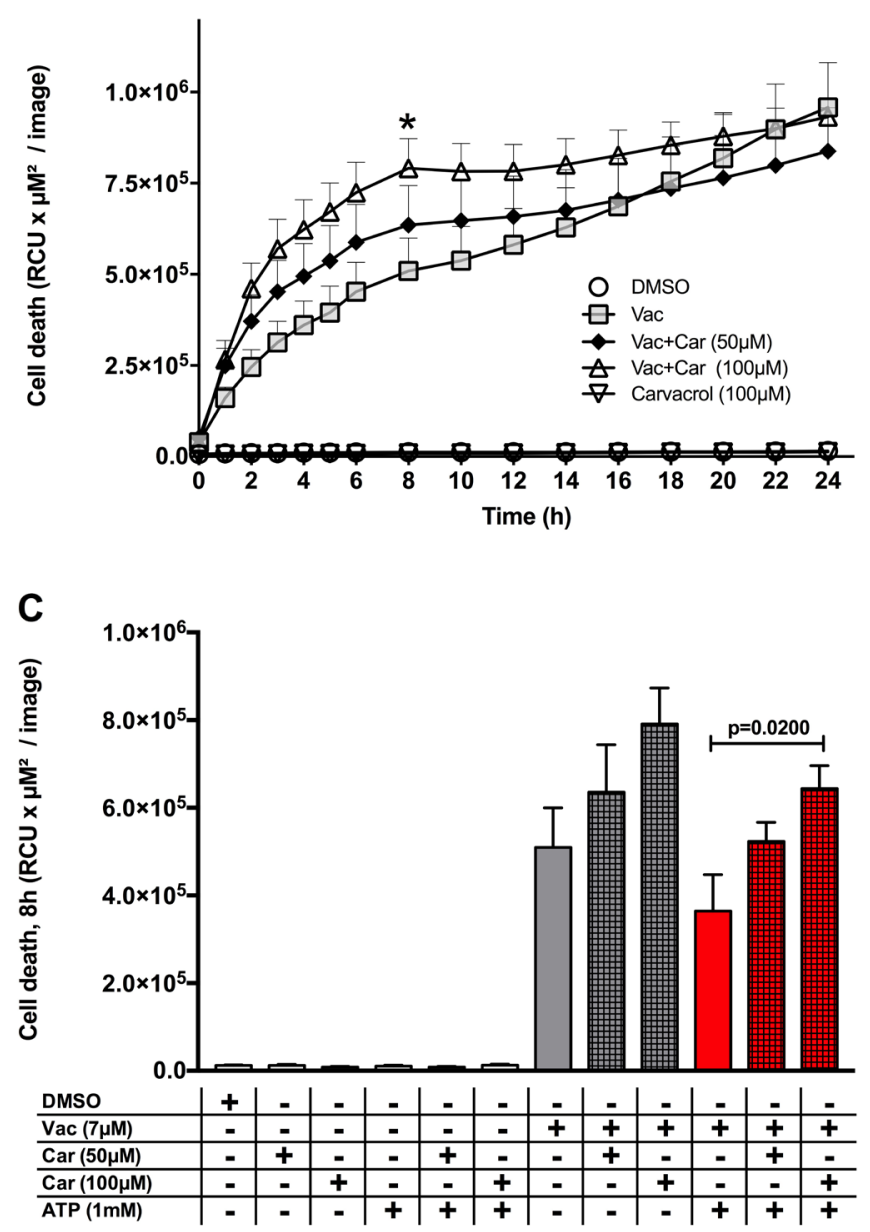

B

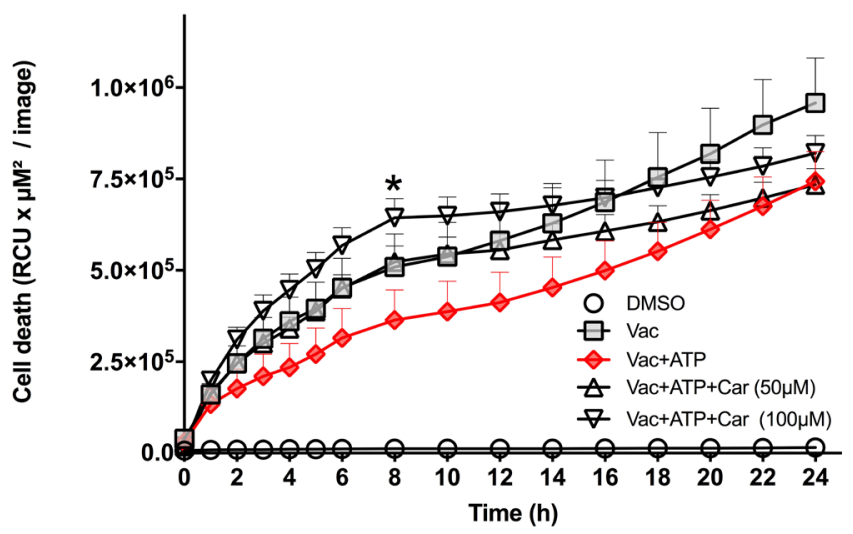

Figure 5: Carvacrol influences the ATP-recovery effect on Vac-induced cell death. Semi-confluent \#12537-GB cells (seeded in 96-well flat-bottomed microtiter plates) were treated with DMSO diluted in medium at $10^{-4}$ served as control, Vac $(7 \mu \mathrm{M})$, Vac $+\mathrm{ATP}$ or ATP without carvacrol or with $50 \mu \mathrm{M}$ and $100 \mu \mathrm{M}$ carvacrol. PI-positive (dead) cells are given as RCU (y-axis, RCU× $\mu \mathrm{M}^{2} / \mathrm{image}$ ). Glioma cells were followed for $24 \mathrm{~h}$ (x-axis) (IncuCyteZOOM $\left.{ }^{\circledR}\right)(\mathbf{A}, \mathbf{B})$. Quantitative analysis at $8 \mathrm{~h}$ for glioma cell lines $(*$ in A and B) (C). Vac + ATP vs. Vac + ATP + carvacrol $100 \mu \mathrm{M}$ (multiple comparison two way ANOVA, $\mathrm{p}=0.02$ ). All values are given as means \pm SD (6× replicates). All imaging was performed using IncuCyteZOOM ${ }^{\circledR}$ at $10 \times$ objective. Results are representative of 3 independent experiments. 
contrast, at lower concentrations, addition of ATP had little if any effect (100 nM ATP), or even increased (10 nM ATP) Vac-induced cell death (Figure 4A).

High ATP concentrations (from $1 \mu \mathrm{M}$ up to $1 \mathrm{mM}$ ) have been reported to occur in vivo in the extracellular space under pathophysiological conditions, including hypoxia [37]. Our findings suggest the contribution of different ATP receptors with distinct ATP affinities in preventing or increasing the Vac-induced cell death. P2X4 and P2X7 have been identified in \#12537-GB (Supplementary Figure 4).

ATP at $1-10 \mu \mathrm{M}$ potentially activates $\mathrm{P} 2 \mathrm{X} 1, \mathrm{P} 2 \mathrm{X} 2$, $\mathrm{P} 2 \mathrm{X} 3, \mathrm{P} 2 \mathrm{X} 4, \mathrm{P} 2 \mathrm{X} 5$ and $\mathrm{P} 2 \mathrm{X} 6$, whereas $\mathrm{P} 2 \mathrm{X} 7$ possesses lower affinity $\left(\mathrm{EC}_{50}>100 \mu \mathrm{M}\right)[12,38]$. In addition to the ionotropic $\mathrm{P} 2 \mathrm{X}$ receptors, ATP acts as an agonist on the metabotropic P2Y receptors: P2Y2, $\left(\mathrm{EC}_{50}=100 \mathrm{nM}\right)$, P2Y11 $\left(\mathrm{EC}_{50}=17 \mu \mathrm{M}\right)$ and P2Y13 $\left(\mathrm{EC}_{50}=260 \mu \mathrm{M}\right)$ [38]. To address the involvement of purinergic receptors, we applied $30 \mu \mathrm{M}$ suramin, a nonselective potent inhibitor of $\mathrm{P} 2$ receptors $[12,14]$ and the selective $\mathrm{P} 2 \mathrm{X} 7$ inhibitor A-438079 [12]. Both inhibitors failed to impair the recovery effect of $1 \mathrm{mM}$ ATP on Vac-induced cell death (Figure 4B, 4C, respectively). By contrast, these inhibitors even increased the ATP-mediated recovery effect on Vac-induced cell death. These findings suggest that purinergic signaling does not contribute to the observed ATP-related counter regulatory effect at $1 \mathrm{mM}$ ATP. Indeed, the simple observation that a complete salvage effect by ATP (TRPM7 mediated) could not been obtained can be explained by the function of purinergic receptors. This explanation is supported by experiments performed in the presence of suramin or A-438079 (see above, Figure 4B, 4C).

Overall, the ATP-inducible and carvacrol-sensitive ion channel TRPM7 plays a major role in Vac-induced methuosis (Figure 5), as exemplified by Chen et al. [19]. TRPM7 is frequently overexpressed in malignant cells as well as in our glioma cell lines (Supplementary Figure 5). Activation by exogenous ATP [13] stimulates the influx of divalent metal ions (e.g. $\mathrm{Ca}^{++}$and $\mathrm{Mg}^{++}$) $[39,40]$, which is essential for mammalian $\mathrm{Mg}^{++}$homeostasis [41]. Recently, an important influence of TRPM7-mediated $\mathrm{Mg}^{++}$influx on PI3K activity was reported by Sahni and Scharenberg [42]. Because PI3K activation leads to improved

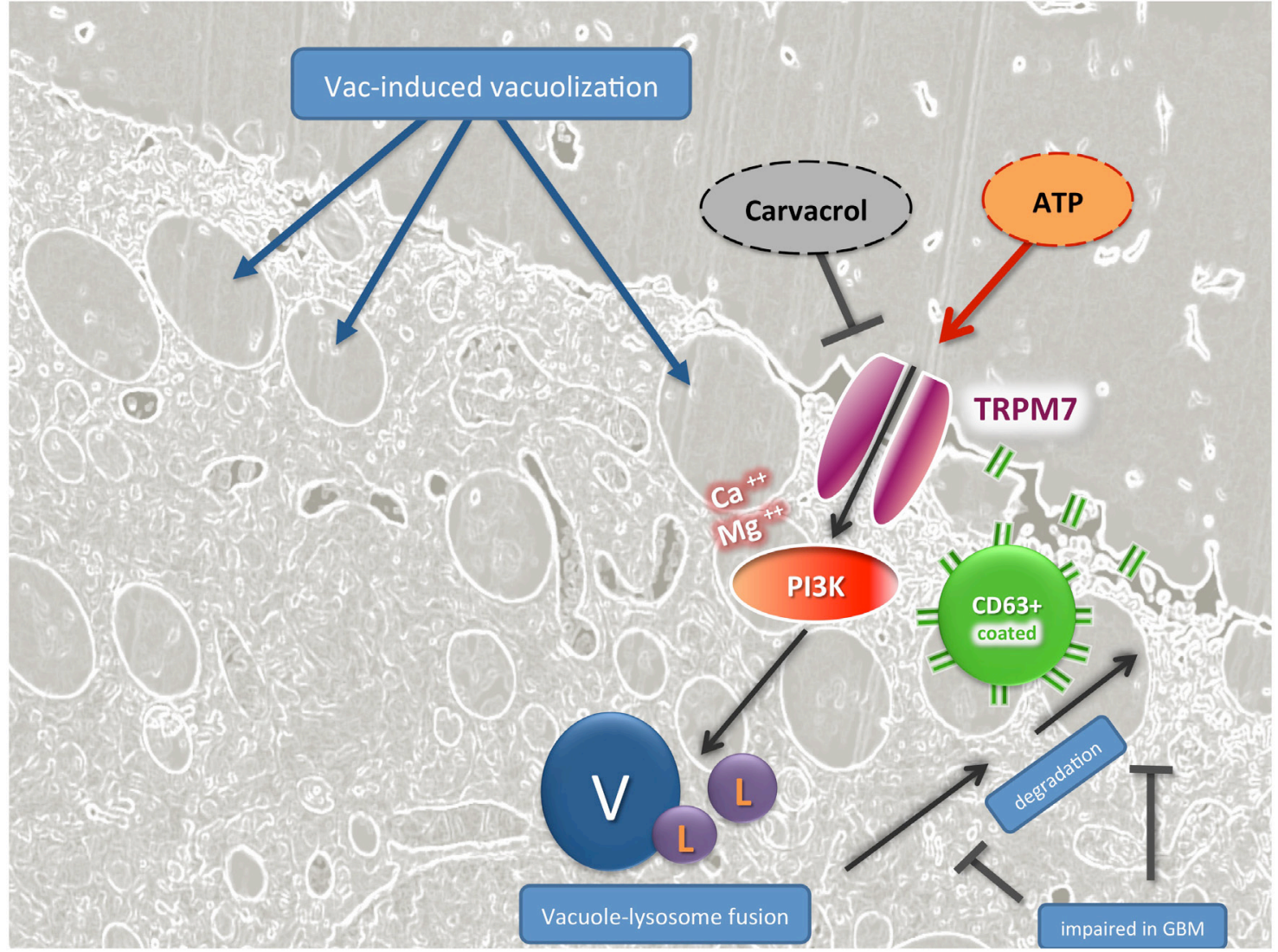

Figure 6: TRPM7-guided signaling in ATP-mediated counter regulation of Vac-induced cell death in GBM, hypothetical mode of action. Fluorescence-based light microscopy and trans electron-microscopical imaging showed that Vac leads to massive vacuolization (V) related to macropinocytosis and autophagy, followed by cell death. This cartoon hypothesizes that exogenous ATP may activate $\mathrm{Ca}$-signaling by TRPM7 activation, $\mathrm{Ca}^{++}$and $\mathrm{Mg}^{++}$influx and PI3K activation, which may promote vesicle fusion (V) with lysosomes (L), and subsequent degradation by CD63-targeted vesicle extrusion. TRPM7-specific effects by exogenous ATP are sensitive to carvacrol, an effective inhibitor of TRPM7-related signaling in GBM. 
endosomal trafficking (Figure 6, [30, 31]), this may at least in part explain the ATP-mediated recovery effect on Vac-induced methuosis. Indeed, inhibition of the observed ATP-mediated inhibitory effect on the Vac-induced cell death by carvacrol emphasizes the involvement of TRPM7 (Figures 5, 6) [19]. Further compounds that inhibit TRPM7 are currently being investigated to further confirm the role of TRPM7 in methuosis [43].

Vac induces a dramatic cell death featuring rupture of the plasma membrane, termed methuosis. Extracellular ATP, an important danger signal in cancer [20], might limit Vac-induced cell death when Vac is applied in vivo. A remarkable feature of GBM with a highly unfavorable outcome [9] are the large necrotic foci [44], which may be a source of extracellular ATP [11, 45]. Therefore necrotic areas constitute a potentially important prognostic factor to be considered for the development of Vac-based treatment protocols in future.

In conclusion, Vac induces a non-apoptotic cell death despite caspase $3 / 7$ activation in glioma cells but does not affect the viability of multipotent DPSCs. According to our findings, Vac-induced cell death is highly efficient when compared to established apoptosis inducing drugs like Temozolomide. However, methuosis induced by Vac is sensitive to extracellular ATP likely mediated by TRPM7 activation. Accordingly, TRPM7 inhibition may be considered as an important therapeutic option improving Vac-induced methuosis once Vac enters the clinical phase. Although promising, such in-vitro studies remain limited unless an appropriate transfer to a clinically relevant model can been achieved.

\section{MATERIALS AND METHODS}

\section{Cell lines and cell culture}

The glioma cell line \#12537-GB was established from primary tumor material as described below (approved by the local Ethics Committee of the University Hospital Ulm; universal trial number: U111-1179-3127) with patient-informed consent. The tumor material was minced and cells from the tumor material were taken into culture by trypsinization of the tumor material (2.5\% trypsin), followed by Ficoll separation. Continuous cultures were performed in Iscove's Modified Dulbecco's Medium (IMDM) (Lonza.com, USA) supplemented with 10\% fetal calf serum (FCS, endotoxin-free, Batch 0247x, Merck/ Biochrom.com, Germany), GlutaMAX (ThermoFisher. com, USA) and antibiotics at $37^{\circ} \mathrm{C}$ under $5 \% \mathrm{CO}_{2}$. Two volunteers donated their third molars to establish DPSCs. Pulpa tissue was mechanically dissected and trypsinized from the third molars, followed by culture in IMDM containing 10\% endotoxin-free FCS (Batch No.: 0247x, Merck/Biochrom.com), further details were according to Cvicl et al. [46].
The glioma cell line \#12537-GB (passage >100) was established from a 63 year-old male patient diagnosed with temporo-parietal (right) localized primary GBM (World Health Organization Grade IV) with a sarcomatous component, isocitrate dehydrogenase $1 / 2$ wild type, O6methylguanine-DNA methyltransferase not methylated and with multiple chromosomal aberrations. The tumor material was derived from a relapse (localization temperooccipital, left), which occurred 5 months after surgical resection followed by adjuvant radiochemotherapy (3 cycles Temozolomide, radiation: $60 \mathrm{~Gy}$ ). The recurrent tumor (WHO grade IV) displayed necrotic regions characteristic for GBM. The phenotype of the cell line derived from this tumor material was assessed by flow cytometry comprising surface (Supplementary Table 1) and cytoplasmic staining (Supplementary Table 2). Results were compared with the commercially available glioma cell line U-87 (ATCC.org) and DPSCs (passage 3) established in this laboratory.

\section{Experiments using the IncuCyteZOOM ${ }^{\circledR}$ incubator microscope}

For stimulation experiments, cells were trypsinized and seeded into transparent flat-bottom 96-well plates (NUNC) at a seeding density of 5,000-cells/well. For IncuCyte experiments, cells were cultured in phenol red and riboflavin-free FluoroBrite Dulbecco's Modified Eagle Medium (DMEM) medium (ThermoFisher.com) supplemented with $10 \%$ FCS, GlutaMAX and antibiotics at $37^{\circ} \mathrm{C}$ under $5 \% \mathrm{CO}_{2}$. Vac (Sellekchem.com, Germany) was dissolved in dimethyl sulfoxide (DMSO) (Sigma. com, USA) to a concentration of $76 \mathrm{mM}$ (155 $\mu$ l were added to $5 \mathrm{mg}$ Vac). ATP (Invivogen.com) was dissolved in sterile water to a concentration of $100 \mathrm{mM}$. Dilutions were made using FluoroBrite DMEM medium. Semiconfluent cell layers seeded into 96-well flat-bottomed microtiter plates (ThermoFisher.com) were treated with a final concentration of $7 \mu \mathrm{M}$ Vac in the presence of 10 $\mu \mathrm{g} / \mathrm{ml}$ PI (Sigma.com) with and without ATP, carvacrol (Sigma.com), suramin (Tocris/Biotechné.com, UK) or A-438079 (Sellekchem.com). Controls were performed with $10^{-4}$ DMSO diluted in medium no toxic effects on glioma cell lines or DPSCs.

After adding the reagents, the plate was inserted into the IncuCyteZOOM ${ }^{\circledR}$ (Essenbio.com, USA). Cell death was quantified as the mean total red integrated fluorescence intensity per image (relative color units $(\mathrm{RCU}) \times \mu \mathrm{M}^{2} /$ image $)$. Data were collected and visualized using GraphPad Prism 7 software. The kinetics of caspase 3/7 activities were determined by the IncuCyte caspase 3/7 assay http://www.essenbioscience.com/en/products/ reagents-consumables/incucyte-96-well-kinetic-caspase37-apoptosis-assay-kit/ Caspase 3/7 activity is presented graphically as the mean total green integrated fluorescence intensity $\left(\mathrm{RCU} \times \mu \mathrm{M}^{2} /\right.$ image $)$. 


\section{Caspase-Glo ${ }^{\circledR}$ 3/7 assay}

Cells were seeded into white non-transparent LumiNunc 96-well flat-bottomed microtiter plates (ThermoFisher.com) at a density of 5,000 cells per well and treated with the respective Vac and ATP concentrations following incubation for $2-6 \mathrm{~h}$ at $37^{\circ} \mathrm{C}$ under $5 \% \mathrm{CO}_{2}$. Thereafter, plates were adjusted to room temperature and Caspase-Glo ${ }^{\circledR}$ 3/7 reagent was added to all wells. Luminescence was determined after $30 \mathrm{~min}$ or longer according to the manufacturer's protocol (Promega.com, USA). The read-out of the luminescence signal (RLUs) was obtained using a GloMax ${ }^{\circledR} 96$ Microplate luminometer (Promega.com).

\section{Phenotype of \#12537-GB: P2X1, P2X4 and P2X7}

P2X1 (APR-001), P2X4 (APR-002) and P2X7 (APR-004) antibodies were purchased from Alomone (Alomone.com, Israel). For flow cytometry, cells were detached using accutase (Sigma.com). For each staining tube, $1 \times 10^{4}$ cells were used. Cells were fixed and permeabilized using Perm/Fix (BDbiosciences. com, USA), followed by two washes with Perm/Wash (BDbiosciences.com) and stained using the respective antibodies, washed with sodium azide buffer $(0.01 \%$ $\mathrm{NaN}_{3}$ and $0.025 \%$ FCS) and fixed with BD CellFix (BDbiosciences.com). For P2X1 and P2X4, cells were stained using secondary antibody (goat anti-rabbit antibody ( $\operatorname{IgG~} \mathrm{F}\left(\mathrm{ab}^{\prime}\right)_{2}$ fragment adsorbed for human proteins), Rockland.com, USA). Secondary antibody staining alone served as negative controls. Ten thousands cells were counted with a FACSCalibur (BDbiosciences. com). Evaluation was performed using Cellquest software v5 (BDbiosciences.com) and FlowJo software v10 (FlowJo.com, USA).

\section{Flow cytometry for glioma cell lines and DPSC}

For cytoplasmic staining, cells were fixed and permeabilized using Perm/Fix (BDbiosciences. com), followed by two washes with Perm/Wash (BDbiosciences.com) and stained for $20 \mathrm{~min}$ using the respective antibodies (Supplementary Table 2, 3), washed with sodium azide buffer and fixed with BD CellFix $(1 \times)$. For surface staining, cells were detached using accutase (Sigma.com) and stained with the respective antibodies (Supplementary Table 1,3), washed with sodium azide buffer and fixed with BD CellFix $(1 \times)$. Ten thousands cells were counted with a FACSCalibur (BDbiosciences.com). Evaluation was performed using Cellquest software (BDbiosciences.com). Mean fluorescence intensity (MFI) values were calculated using the following formula: $\%$ positive of gated cells $\mathrm{x}$ $\mathrm{X}$-mean or Y-mean.

\section{Quantitative real-time PCR (qPCR)}

Total RNA was extracted using the Maxwell $^{\circledR}$ 16 LEV simply RNA kit (Promega.com) according to the manufacturer's instruction. In total, 400 ng RNA were used for cDNA first-strand synthesis using the GoScript Reverse Transcription System (Promega.com) according to the manufacturer's instruction. cDNA was diluted $1 / 10$ for qPCR; $4 \mu \mathrm{l}$ were used for qPCR. qPCR was performed using TaqMan Gene expression assays (RPL13: Hs00744303_s1, TRPM7: Hs00559080_m1) and a StepOne System (ThermoFisher.com) according to the manufacturer's protocol. PCR conditions: $2 \mathrm{~min} 50^{\circ} \mathrm{C}$, $10 \mathrm{~min} 95^{\circ} \mathrm{C}$ followed by 40 cycles comprising $15 \mathrm{~s} 95^{\circ} \mathrm{C}$ (denaturation) and $1 \mathrm{~min} 60^{\circ} \mathrm{C}$ (annealing/extension). Data are presented as fold change (Relative Quantity (RQ)) relative to RPL13 as endogenous control. DPSCs were used as the reference sample. Technical triplicates were performed.

\section{Electron microscopy}

Sapphire discs (Engineering Office M. Wohlwend $\mathrm{GmbH}$, Switzerland) were used as support for the adherent glioma cell culture. The $0.170-\mathrm{mm}$ thick discs were cleaned by sonication for $15 \mathrm{~min}$ each in $60 \%$ sulfuric acid, soapy water and twice in absolute ethanol, and allowed to dry. The discs were then coated with approximately $20 \mathrm{~nm}$ carbon by electron-beam evaporation and dried for $8 \mathrm{~h}$ or overnight in an oven at $120^{\circ} \mathrm{C}$ to increase the carbon-film stability. The coated sapphire discs were then carefully immersed in complete medium and the cells were seeded on top. A $50-\mu \mathrm{m}$ gold spacer ring (diameter $3.05 \mathrm{~mm}$, central bore $2 \mathrm{~mm}$; Plano GmbH, Germany) was mounted in between two coated sapphire discs with the cells grown on them, similar to the protocol introduced by Hawes et al. [47]. These sandwiches were high-pressure frozen without aluminum planchettes and without the use of hexadecene. Freeze substitution was performed as described in Walther and Ziegler [48] and Buser and Walther [49] with a substitution medium consisting of acetone with $0.2 \%$ osmium tetroxide, $0.1 \%$ uranyl acetate and 5\% water for $19 \mathrm{~h}$. During this time period, the temperature was exponentially raised from $183 \mathrm{~K}$ to $273 \mathrm{~K}$. After substitution, the samples were maintained at room temperature for $30 \mathrm{~min}$ and then washed twice with acetone. After stepwise embedding of the samples in Epon (Fluka.com, USA) (polymerization at $333 \mathrm{~K}$ within $72 \mathrm{~h}$ ), they were cut using a microtome (Leica Ultracut UCT ultramicrotome) with a diamond knife (Diatome, Switzerland) to semi-thin sections with a nominal thickness of $500 \mathrm{~nm}$ or $1 \mu \mathrm{m}$, as measured from the readout of the microtome. Specimens were examined using a JEOL 1400 (JEOL.com, Germany) at $120 \mathrm{keV}$. 


\section{Statistical analysis}

Statistical analysis was performed using GraphPadPrism v7 (Graphpad.com, USA). To identify significant differences between treatments over the entire time frame, regular two-way ANOVA was performed. $\mathrm{P}$-values of single time points of kinetics were calculated by multiple comparison tests after two-way ANOVA. Sidak's correction was applied to correct for multiple comparisons. P-values of caspase 3/7 Glo assays were calculated using unpaired two-tailed t-test with Welch's correction. Observations with $\mathrm{p}<0.05$ were considered as significant.

\section{Abbreviations}

Car: Carvacrol; DPSCs: Dental-pulp stem cells; GBM: Glioblastoma multiforme; GFAP: Glial fibrillary acidic protein; MFI: Mean fluorescence intensity; MIC-A: MHC class I polypeptide-related sequence A; RCU: Relative color units; RLU: Relative luminescence units; STS: Staurosporine; Vac: Vacquinol-1; VEGF: Vascular endothelial growth factor; zVAD-FMK: Carbobenzoxy-valyl-alanyl-aspartyl-[O-methyl]fluoromethylketone.

\section{Author contributions}

PS wrote the MS and performed experiments. HM contributed to experiments and study design. AS performed experiments. JMS performed analysis and graphical work-up. AP contributed patients' materials. AKB established DPSCs. BM performed experiments. CRW and MG contributed clinical work-up. EMS wrote the manuscript, established cell lines and supervised experiments.

\section{ACKNOWLEDGMENTS}

We thank Andrew Westhoff for his contribution in conceptual discussions and Annika Dwucet for cell-culture contribution; Paul Walther for electron microscopy; Alexandra Gelwer and Daniel Gutkowski for DPSC culture.

\section{CONFLICTS OF INTEREST}

The authors declare that there are no conflicts of interest in this paper.

\section{GRANT SUPPORT}

PS and HM are fellows of the International Graduate School in Molecular Medicine, Ulm University (IGradU).

\section{REFERENCES}

1. Merzak A, Pilkington GJ. Molecular and cellular pathology of intrinsic brain tumours. Cancer Metastasis Rev. Netherlands; 1997; 16: 155-77.

2. Maher EA, Furnari FB, Bachoo RM, Rowitch DH, Louis DN, Cavenee WK, DePinho RA. Malignant glioma: Genetics and biology of a grave matter. Genes Dev. 2001; 15: 1311-33. doi: 10.1101/gad.891601.

3. Sontheimer H. Malignant gliomas: Perverting glutamate and ion homeostasis for selective advantage. Trends in Neurosciences. 2003; 26:543-9. doi: 10.1016/j. tins.2003.08.007.

4. Khusial PR, Vadla B, Krishnan H, Ramlall TF, Shen Y, Ichikawa H, Geng JG, Goldberg GS. Src activates Abl to augment Robo1 expression in order to promote tumor cell migration. Oncotarget. 2010; 1: 198-209. doi: 10.1016/j. bbi.2008.05.010.

5. Panicker SP, Raychaudhuri B, Sharma P, Tipps R, Mazumdar T, Mal AK, Palomo JM, Vogelbaum MA, Haque SJ. p300- and Myc-mediated regulation of glioblastoma multiforme cell differentiation. Oncotarget. 2010; 1:289303. doi: 10.18632/oncotarget.100801.

6. Mostafa H, Pala A, Högel J, Hlavac M, Dietrich E, Westhoff MA, Nonnenmacher L, Burster T, Georgieff M, Wirtz CR, Schneider EM. Immune phenotypes predict survival in patients with glioblastoma multiforme. J Hematol Oncol. 2016; 9: 77. doi: 10.1186/s13045-016-0272-3.

7. Kmiecik J, Poli A, Brons NHC, Waha A, Eide GE, Enger PØ, Zimmer J, Chekenya M. Elevated CD3+ and CD8+ tumor-infiltrating immune cells correlate with prolonged survival in glioblastoma patients despite integrated immunosuppressive mechanisms in the tumor microenvironment and at the systemic level. J Neuroimmunol. 2013; 264: 71-83. doi: 10.1016/j. jneuroim.2013.08.013.

8. Kitambi SS, Toledo EM, Usoskin D, Wee S, Harisankar A, Svensson R, Sigmundsson K, Kalderén C, Niklasson M, Kundu S, Aranda S, Westermark B, Uhrbom L, et al. Vulnerability of glioblastoma cells to catastrophic vacuolization and death induced by a small molecule. Cell. 2014; 157: 313-28. doi: 10.1016/j.cell.2014.02.021.

9. Barker FG, Davis RL, Chang SM, Prados MD. Necrosis as a prognostic factor in glioblastoma multiforme. Cancer. 1996; 77: 1161-6.

10. Pala A, Brand C, Kapapa T, Hlavac M, König R, Schmitz B, Wirtz CR, Coburger J. The Value of Intraoperative and Early Postoperative Magnetic Resonance Imaging in Low-Grade Glioma Surgery: A Retrospective Study. World Neurosurg. 2016; 93: 191-7. doi: 10.1016/j. wneu.2016.04.120.

11. Noch E, Khalili K. Molecular mechanisms of necrosis in glioblastoma: The role of glutamate excitotoxicity. Cancer Biol Ther. 2009; 8: 1791-7. doi: 10.4161/cbt.8.19.9762. 
12. Kügelgen I Von. Pharmacology of mammalian P2X- and P2Y-receptors. Biotrend Rev. 2008; 3: 1-12.

13. Nörenberg W, Plötz $T$, Sobottka $H$, Chubanov V, Mittermeier L, Kalwa H, Aigner A, Schaefer M. TRPM7 is a molecular substrate of ATP-evoked P2X7-like currents in tumor cells. J Gen Physiol. 2016; 147: 467-83. doi: 10.1085/jgp.201611595.

14. Morrone FB, Jacques-Silva MC, Horn AP, Bernardi A, Schwartsmann G, Rodnight R, Lenz G. Extracellular nucleotides and nucleosides induce proliferation and increase nucleoside transport in human glioma cell lines. J Neurooncol. 2003; 64: 211-8. doi: 10.1023/A:1025699932270.

15. Yee NS, Kazi AA, Yee RK. Cellular and Developmental Biology of TRPM7 Channel-Kinase: Implicated Roles in Cancer. Cells. 2014; 3: 751-77. doi: 10.3390/cells3030751.

16. Meng X, Cai C, Wu J, Cai S, Ye C, Chen H, Yang Z, Zeng H, Shen Q, Zou F. TRPM7 mediates breast cancer cell migration and invasion through the MAPK pathway. Cancer Lett. 2013; 333: 96-102. doi: 10.1016/j.canlet.2013.01.031.

17. Kim BJ, Nah SY, Jeon JH, So I, Kim SJ. Transient Receptor Potential Melastatin 7 Channels are Involved in Ginsenoside Rg3-Induced Apoptosis in Gastric Cancer Cells. Basic Clin Pharmacol Toxicol. 2011; 109: 233-9. doi: 10.1111/j.1742-7843.2011.00706.x.

18. Rybarczyk P, Gautier M, Hague F, Dhennin-Duthille I, Chatelain D, Kerr-Conte J, Pattou F, Regimbeau JM, Sevestre H, Ouadid-Ahidouch H. Transient receptor potential melastatin-related 7 channel is overexpressed in human pancreatic ductal adenocarcinomas and regulates human pancreatic cancer cell migration. Int J Cancer. 2012; 131: E851-61. doi: 10.1002/ijc.27487.

19. Chen WL, Barszczyk A, Turlova E, Deurloo M, Liu B, Yang BB, Rutka JT, Feng ZP, Sun HS. Inhibition of TRPM7 by carvacrol suppresses glioblastoma cell proliferation, migration and invasion. Oncotarget. 2015; 6: 16321-40. doi: 10.18632/oncotarget.3872.

20. Burnstock G, Di Virgilio F. Purinergic signalling and cancer. Purinergic Signal. 2013; 9: 491-540. doi: 10.1007/ s11302-013-9372-5.

21. Belmokhtar CA, Hillion J, Ségal-Bendirdjian E. Staurosporine induces apoptosis through both caspasedependent and caspase-independent mechanisms. Oncogene. 2001; 20: 3354-62. doi: 10.1038/ sj.onc. 1204436.

22. Sawai H, Domae N. Discrimination between primary necrosis and apoptosis by necrostatin-1 in Annexin V-positive/propidium iodide-negative cells. Biochem Biophys Res Commun. 2011; 411: 569-73. doi: 10.1016/j. bbrc.2011.06.186.

23. Overmeyer JH, Young AM, Bhanot H, Maltese WA. A chalcone-related small molecule that induces methuosis, a novel form of non-apoptotic cell death, in glioblastoma cells. Mol Cancer. 2011; 10: 69. doi: 10.1186/1476-4598-10-69.
24. Overmeyer JH, Kaul A, Johnson EE, Maltese WA. Active ras triggers death in glioblastoma cells through hyperstimulation of macropinocytosis. Mol Cancer Res. 2008; 6: 965-77. doi: 10.1158/1541-7786.MCR-07-2036.

25. Maltese WA, Overmeyer JH. Methuosis: Nonapoptotic cell death associated with vacuolization of macropinosome and endosome compartments. Am J Pathol. 2014; 184: 1630-42. doi: 10.1016/j.ajpath.2014.02.028.

26. Maltese WA, Overmeyer JH. Non-apoptotic cell death associated with perturbations of macropinocytosis. Front Physiol. 2015; 6: 1-10. doi: 10.3389/fphys.2015.00038.

27. Bansal R, Jain A. Current overview on dental stem cells applications in regenerative dentistry. J Nat Sci Biol Med. 2015; 6: 29-34. doi: 10.4103/0976-9668.149074.

28. Bhanot H, Young AM, Overmeyer JH, Maltese WA. Induction of Nonapoptotic Cell Death by Activated Ras Requires Inverse Regulation of Rac1 and Arf6. Mol Cancer Res. 2010; 8: 1358-74. doi: 10.1158/1541-7786. MCR-10-0090.

29. Flannagan RS, Jaumouillé V, Grinstein S. The cell biology of phagocytosis. Annu Rev Pathol. 2012; 7: 61-98. doi: 10.1146/annurev-pathol-011811-132445.

30. Vieira O V, Bucci C, Harrison RE, Trimble WS, Lanzetti L, Gruenberg J, Schreiber AD, Stahl PD, Grinstein S. Modulation of Rab5 and Rab7 recruitment to phagosomes by phosphatidylinositol 3-kinase. Mol Cell Biol. 2003; 23: 2501-14. doi: 10.1128/MCB.23.7.2501-2514.2003.

31. Jean S, Kiger AA. Classes of phosphoinositide 3-kinases at a glance. J Cell Sci. 2015; 923-8. doi: 10.1242/jcs.093773.

32. Nan YN, Zhu JY, Tan Y, Zhang Q, Jia W, Hua Q. Staurosporine Induced Apoptosis Rapidly Downregulates TDP- 43 in Glioma Cells. Asian Pac J Cancer Prev. 2014; 15: 3575-9. doi: 10.7314/APJCP.2014.15.8.3575.

33. Simenc J, Lipnik-Stangelj M. Staurosporine induces different cell death forms in cultured rat astrocytes. Radiol Oncol. 2012; 46: 312-20. doi: 10.2478/v10019-012-0036-9.

34. Yu L, Lenardo MJ, Baehrecke EH. Authophagy and Caspases: A New Cell Death Program. Cell Cycle. 2004; 3: 1124-6. doi: 10.4161/cc.3.11.1203.

35. González-Polo RA, Boya P, Pauleau AL, Jalil A, Larochette $\mathrm{N}$, Souquère $\mathrm{S}$, Eskelinen EL, Pierron G, Saftig $\mathrm{P}$, Kroemer G. The apoptosis/autophagy paradox: autophagic vacuolization before apoptotic death. J Cell Sci. 2005; 118: 3091-102. doi: 10.1242/jcs.02447.

36. Liu Y, Levine B. Autosis and autophagic cell death: the dark side of autophagy. Cell Death Differ. 2015; 22: 367-76. doi: 10.1038/cdd.2014.143.

37. Di Virgilio F. Purines, purinergic receptors, and cancer. Cancer Res. 2012; 72: 5441-7. doi: 10.1158/0008-5472. CAN-12-1600.

38. Junger WG. Immune cell regulation by autocrine purinergic signalling. Nat Rev Immunol. 2011; 11: 201-12.

39. Nadler MJ, Hermosura MC, Inabe K, Perraud AL, Zhu Q, Stokes AJ, Kurosaki T, Kinet JP, Penner R, Scharenberg 
AM, Fleig A. LTRPC7 is a Mg.ATP-regulated divalent cation channel required for cell viability. Nature. 2001; 411: 590-5. doi: 10.1038/35079092.

40. Monteilh-Zoller MK, Hermosura MC, Nadler MJS, Scharenberg AM, Penner R, Fleig A. TRPM7 Provides an Ion Channel Mechanism for Cellular Entry of Trace Metal Ions. J Gen Physiol. 2003; 121: 49-60. doi: 10.1085/ jgp. 20028740.

41. Ryazanova LV, Rondon LJ, Zierler S, Hu Z, Galli J, Yamaguchi TP, Mazur A, Fleig A, Ryazanov AG. TRPM7 is essential for $\mathrm{Mg}(2+)$ homeostasis in mammals. Nat Commun. 2010; 1: 109. doi: 10.1038/ncomms1108.

42. Sahni J, Scharenberg AM. TRPM7 Ion Channels Are Required for Sustained Phosphoinositide 3-Kinase Signaling in Lymphocytes. Cell Metab. 2008; 8: 84-93. doi: 10.1016/j.cmet.2008.06.002.

43. Chubanov V, Schäfer S, Ferioli S, Gudermann T. Natural and Synthetic Modulators of the TRPM7 Channel. Cells. 2014; 3: 1089-101. doi: 10.3390/cells3041089.

44. Laws ER, Shaffrey ME. The inherent invasiveness of cerebral gliomas: Implications for clinical management. Int J Dev Neurosci. 1999; 17: 413-20. doi: 10.1016/ S0736-5748(99)00013-1.
45. Iyer SS, Pulskens WP, Sadler JJ, Butter LM, Teske GJ, Ulland TK, Eisenbarth SC, Florquin S, Flavell RA, Leemans JC, Sutterwala FS. Necrotic cells trigger a sterile inflammatory response through the Nlrp3 inflammasome. Proc Natl Acad Sci U S A. 2009; 106: 20388-93. doi: 10.1073/pnas.0908698106.

46. Cvikl B, Agis H, Stögerer K, Moritz A, Watzek G, Gruber $\mathrm{R}$. The response of dental pulp-derived cells to zoledronate depends on the experimental model. Int Endod J. 2011; 44: 33-40. doi: 10.1111/j.1365-2591.2010.01792.x.

47. Hawes P, Netherton CL, Mueller M, Wileman T, Monaghan P. Rapid freeze-substitution preserves membranes in highpressure frozen tissue culture cells. J Microsc. 2007; 226: 182-9. doi: 10.1111/j.1365-2818.2007.01767.x.

48. Walther P, Ziegler A. Freeze substitution of highpressure frozen samples: The visibility of biological membranes is improved when the substitution medium contains water. J Microsc. 2002; 208: 3-10. doi: 10.1046/j.1365-2818.2002.01064.x.

49. Buser C, Walther P. Freeze-substitution: The addition of water to polar solvents enhances the retention of structure and acts at temperatures around -60. C. J Microsc. 2008; 230: 268-77. doi: 10.1111/j.1365-2818.2008.01984.x. 